\title{
Beton Gürültü Bariyeri İçin Perlit Kaplama ve Maliyeti
}

\author{
Metehan ÇALIŞ ${ }^{1}$ \\ Zübeyde ÖZTÜRK
}

\section{$\ddot{O Z Z}$}

Bu çalışmada; karayolu trafiği kaynaklı çevresel gürültü ile mücadele yöntemlerinden biri olan gürültü bariyerlerinde ses yutuculuğun arttırılması amacı ile özellikle beton bariyerler üzerinde uygulanabilecek olan perlit esaslı bir kaplamanın tasarlanması, fiziksel ve akustik özelliklerinin deneysel olarak belirlenmesi ve maliyetleri açısından değerlendirilmesi yapılmaktadır. Çalışmanın devamında elde edilen gürültü seviyesindeki azalma ve gürültüden etkilenen kişi sayısındaki azalma miktarı ekonomik bir fayda olarak ele alınıp, bariyerin inşa maliyeti ve işletme maliyetleri ile karşılaştırılarak perlitli kaplamanın, belli kabuller altında, 50 yıllık yapı ömrü ile inşa edilmesinin ekonomik olup olmayacağı araştırılmıştır.

Anahtar Kelimeler: Betonarme gürültü bariyeri, perlit kaplama, ekonomik analiz.

\begin{abstract}
\section{Perlite Coating for Concrete Noise Barriers and its Cost}

In this stud, perlite based coatings which can be applied to increase sound absorption capability of noise barriers, and especially use of concrete noise barriers, which is one of the forthcoming methods for overcoming the effects of environmental noise in urban areas caused by highway traffic, is examined in terms of design, experimental evaluation of physical and acoustic performance and costs. In the following stages of the study, considering decrease in the noise level in urban areas and reduction in the number of people adversely affected by traffic noise as economical benefits and comparing these with noise barrier construction and operation costs, also with application of perlite based coating, were evaluated, under certain assumptions, to evaluate its economic feasibility during the 50 years assumed life span of a concrete noise barrier.
\end{abstract}

Keywords: Concrete noise barrier, perlite covering, economic analysis.

\footnotetext{
Not: Bu yaz1

- Yayın Kurulu'na 01.07.2016 günü ulaşmıştır. 18.04.2017 günü yayımlanmak üzere kabul edilmiştir.

- 31 Temmuz 2018 gününe kadar tartışmaya açıktır.

- DOI: $10.18400 /$ tekderg.378524
}

1 TSE Yapı Malzemeleri Yangın ve Akustik Laboratuvar Müdürlügüu, İstanbul - mcalis@tse.org.tr

2 İstanbul Teknik Üniversitesi, İnşaat Mühendisliği Bölümü, İstanbul - ozturkzu@itu.edu.tr 


\section{GİRIŞ}

Mevzuatta yer almasına rağmen, ülkemizde gürültü önlemleri yeterince uygulanmamaktadır. Ülkemizde yeni yeni gündeme gelmeye başlayan bu önlem türü, Avrupa ve Amerika'daki birçok ülkede yaşam alanları için standart bir çözüm olarak yer almaktadır. Bu makale yazar tarafından yapılan doktora tezinden hazırlanmış olup, çalışmanın bir kısmında, 'Çevresel Gürültünün Değerlendirilmesi ve Yönetimi Yönetmeliği’ gereği yaşam alanlarında sağlanması gereken gürültü değerlerinin aşılmaması için, trafik kaynaklı gürültünün azaltılmasında kullanılan genellikle gürültü yansıtıcı özellikteki betonarme gürültü bariyerlerinin inşa ve işletme maliyetleri araştırılmıştır [1]. Çalışmanın pratikte yer alan malzeme geliştirme kısmı, Avrupa Standartlarına uygun şekilde laboratuvar ortamında yapılan deneyler ile desteklenmiştir. Çalışma deneysel, teorik ve hesaba dayalı bölümlere sahip olup, özgündür. Çalışmaya ait teorik ve hesaplama kısmında ise;

- Perlit esaslı kaplama uygulanmış ve uygulanmamış bariyerlerde, gürültü haritalama yazılımı yardımı ile belirli trafik ve çevre koşulları altında gürültü azaltma performans değerleri,

- Gürültü azaltma performansındaki artışa karşılık gelen inşa ve işletme maliyetleri ile Fayda/Maliyet oranlarının hesaplanması,

- İnşa ve İşletme maliyetlerdeki değişimlerin Fayda/Maliyet üzerindeki etkileri,

hakkında elde edilen değerler tablolar ile birlikte karşılaştırmalı olarak ortaya konmuştur. Ancak makale sayfa sınırlandırılması nedeniyle bu doktora tezinin bir bölümü olan ekonomik analiz kısmına ağırlık verilerek hazırlanmıştır.

\section{BETON GÜRÜLTÜ BARIYYERI VE PERLITT KULLANIMI}

\subsection{Beton Bariyer}

Özellikle otoyol kenarlarında kullanımı günden güne artmakta olan gürültü bariyerleri, gürültünün azaltılmasında etkili olmaları sebebiyle oldukça fazla talep almaktadırlar. Bariyerler genellikle 10-15 dB(A) arası bir gürültü azaltımı sağlayabilirler. Beton, üretimi yapısı ile kalitesi kontrol altında tutulabilen, kolay üretilen, oldukça yaygın kullanımı olan bir yap1 malzemesidir. Özellikle beton santrallerindeki ileri teknoloji ve beton üzerine yapılan yoğun Ar-ge çalışmaları sonucu dayanımı yüksek, iklim koşullarına karşı dayanıklı ve her üretimde aynı karakteristikleri sağlayabilen beton üretmek mümkün hale gelmiştir. Beton bariyerlerin diğer bariyer tiplerine göre avantajları şunlardır:

- Beton gürültü perdeleri düşük bakım ihtiyaçları yönüyle en fazla tercih edilen bariyer tipidir.

- $\quad$ Beton, piriz almadan önce veya uygun kalıplar ile beton üzerine istenilen yüzey tipi verilebilmesinden dolayı bununla tasarım yönünden özgün, akustik olarak etkili ve görsel olarak estetik çözümler sunulabilir.

- İmalatında hammadde olarak taş, kum, su ve çimento gibi doğal ve kolay elde edilebilir maddeler kullanıldığından, beton çok zorlu fiziksel şartlar altında dahi yerinde döküm olarak bariyer imalatında kullanılabilir. 
- Nitelikli işçi gereksinimi diğer bariyer tiplerine göre daha azdır.

- Trafik kaynaklı etkilerin yanı sıra kullanımı boyunca alınıp satılabilecek bir özelliği bulunmadığından, boyama hariç diğer vandalizm etkilerine karşı en dayanıklı malzemedir.

- Betonun özgül ağırlığı nedeniyle yüzey kütlesi ve rijitliği oldukça fazladır.

Betonun gürültü perdelerinde kullanımı iki şekilde yapılmaktadır: Yerinde döküm ve prefabrikasyon. Bu iki tip üretimin de birbirine göre avantaj ve dezavantajları vardır. Genellikle projeye göre değerlendirerek bir tercih yapılmalıdır. Tercih aşamasında proje süresi, yerinde imalata uygunluk ve prefabrik imalatın yapıldığı yer ile proje alanı arasındaki uzaklık gibi hususlar dikkate alınmalıdır.

\subsection{Perlit ve Deneysel Çalışma}

Perlit ısıyla genleşme özelliği olan, genleştirildiğinde çok hafif ve gözenekli bir hale geçen volkanik bir kayaçtır. Volkanik kayaçlar kırıldığında oluşan küçük beyaz tanecikler inciye benzediğinden dolayı, perlitin kelime kökeni "perle"dir. Perlit kayaçları renk olarak birbirinden farklı olabilir, ancak tüm perlit kayaçları $850-900^{\circ} \mathrm{C}$ gibi yüksek sıcaklıkta patlatılıp genleştirildikten sonra beyaz rengini alır. Patlayarak genleşme özelliği ile perlit diğer volkanik kayaçlardan ayrılır. Genleşmiş perlitin rengi kar beyazı ile grimsi beyaz tonları arasında değişmektedir. Patlatılmış perlit, ilk hacmine oranla 4-20 kat arasında hacim kazanmaktadır. Perlit içinde \%2-6 arasında değişen oranda su barındırır. Bu su patlatma sırasında yüksek sıcaklık nedeni ile buharlaşarak perlit içinde sayısız küçük baloncuk veya odacık meydana getirir. Bu patlama neticesinde meydana gelen hacim artışı neticesinde kırılmış ham perlitin yaklaşı $1100 \mathrm{~kg} / \mathrm{m}^{3}$ olan ham yoğunluğu patlama sonrasında $30-150$ $\mathrm{kg} / \mathrm{m}^{3}$ değerlerine kadar düşer.

Dünya perlit rezervinin yarısından fazlasının Türkiye'de bulunduğu [2] ve Türkiye'nin muhtemel perlit rezervinin yaklaşık 4,5 milyar ton civarında olduğu tahmin edilmektedir [3]. 2011 yılında dünya'da 1,7 milyon ton perlit üretildiği ve bunun büyük bölümünün Yunanistan, Amerika Birleşik Devletleri, Japonya ve Türkiye tarafindan üretildiği belirtilmektedir [4]. Perlit ülkemizde doğuda Erzurum, Kars, Ermenistan sınırları ile batıda İzmir, Çanakkale, Manisa, Dikili, Bergama dolaylarında çıkarılmaktadır. Orta Anadolu'da ise Ankara ve çevresinde perlit kaynakları bulunmaktadır ve bu kaynaklarda yararlanacak mühendislik projelerinin geliştirilmesi gerekir. Bu amaçla yapılan doktora tezinde perlitin kaplama olarak kullanımı için malzemenin uygunluğuna ve akustik yutuculuk katsayısının belirlenmesine yönelik deneysel ve saha çalışmaları yapılmış olmakla birlikte içerik çok geniş olduğu için bu makalede ekonomik analiz kısmına yer verilmektedir.

Patlatılmış perlitin yapı elemanı olarak 1sı yalıtımı amaçlı kullanılması, ancak akustik yutuculuk özelliğinin daha önce kullanılmaması bu çalışmaya başlamada belirleyici unsur olmuştur. Hem perlitin kendi boşluğunun hem de yapılan işlemlerden sonra elde edilen boşluklu yapının ses yutuculuk anlamında yeterli bir performans göstererek bir gürültü önlemi olarak kullanılması planlanmıştır. İki deney grubu yaklaşık olarak aynı kalınlıkta hazırlanmış olup, sadece tabakalı yapılanmaları yönü ile birbirinden farklıdır. Kullanılan perlit üretim partileri aynıdır, yani yapısal olarak birbirinden farklı değildir. Yapılan fiziksel 
deneylere ait sonuçlarda tasarlanan perlitli plakaların yapısal özelliklerinin önemli ölçüde farklı olmamasından dolayı büyük farklılıklar gözlenmemektedir (Çizelge 1). Özellikle ikinci deney numunesi grubundaki alt ince tabakanın genel yoğunluğu $350 \mathrm{~kg} / \mathrm{m}^{3}$ 'ten $400 \mathrm{~kg} / \mathrm{m}^{3}$ 'e artırmasından dolayı basınç dayanımında da 0,12MPa'dan 0,18MPa'a artış gözlenmiştir. Beton yüzeye yapılan ve tasarlanan perlitli tabakayı beton plakaya bağlayan sıva tabakasının her iki deney grubunda aynı olmasından dolayı, perlit kaplama tabakasının alt tabakaya yapışma mukavemetleri birbirine oldukça yakındır. Çimento esaslı farklı yapıştırıcılar kullanılarak beton yüzeye yapışma mukavemetleri $0,12 \mathrm{MPa}$ 'dan yukarılara çekilebilir.

Çizelge1. Fiziksel deneylerin ölçüm sonuçları.

\begin{tabular}{|c|c|c|c|c|}
\hline $\begin{array}{c}\text { Deney Adı } \\
\text { ve } \\
\text { Standart Numarası }\end{array}$ & $\begin{array}{c}\text { I. Numune } \\
\text { Grubu }\end{array}$ & $\begin{array}{c}\text { II. Numune } \\
\text { Grubu }\end{array}$ & Değişim & Değişim (\%) \\
\hline $\begin{array}{c}\text { TS EN 1015-11 } \\
\text { Basınç Dayanımı }\end{array}$ & $0,12 \mathrm{~N} / \mathrm{mm}^{2}$ & $0,18 \mathrm{~N} / \mathrm{mm}^{2}$ & $0,06 \mathrm{~N} / \mathrm{mm}^{2}$ & $\% 50$ \\
\hline $\begin{array}{c}\text { TS EN 1015-12 } \\
\text { Bağ Dayanımı } \\
\left(\begin{array}{c}1 \text { cm kalınlı̆̆ında perlitli } \\
\text { sıva ile birlikte)* }\end{array}\right.\end{array}$ & $0,12 \mathrm{~N} / \mathrm{mm}^{2}$ & $0,13 \mathrm{~N} / \mathrm{mm}^{2}$ & $0,01 \mathrm{~N} / \mathrm{mm}^{2}$ & $\% 8$ \\
\hline $\begin{array}{c}\text { TS EN 1015-10 } \\
\text { Kuru Birim Hacim Ağırlığ } 1\end{array}$ & $351 \mathrm{~kg} / \mathrm{m}^{3}$ & $405 \mathrm{~kg} / \mathrm{m}^{3}$ & $54 \mathrm{~kg} / \mathrm{m}^{3}$ & $\% 15$ \\
\hline * kopmalar perlitli sıva ile perlit kaplama tabakaları arasından meydana gelmiştir. & \\
\hline
\end{tabular}

Gürültü bariyerlerinin ses yutum özellikleri hesaplanırken, her frekans aralığındaki değerler yerine insan kulağının en hassas olduğu frekans değerleri dikkate alınır. Bu değerler $250 \mathrm{~Hz}$, $500 \mathrm{~Hz}, 100 \mathrm{~Hz}$ ve $2000 \mathrm{~Hz}$ alınarak, malzemenin bu frekanslardaki ses yutum katsayısı değerlerinin aritmetik ortalaması alınıp, bulunan sonuç en yakın 0,05 dB'e yuvarlanır ve malzemenin ses yutum katsayısı tek sayılı bir ifade haline dönüştürülmüş olur. ASTM C 4232a Standardında bu değer Gürültü Azaltma Katsayısı (NRC-Noise Reduction Coefficient) olarak (1) adlandırılmaktadır [5].

$$
N R C=\frac{\alpha_{250}+\alpha_{500}+\alpha_{1000}+\alpha_{2000}}{4}
$$

NRC değeri 1,0'e yakınsa o malzemeler için ses yutucu özellikte malzemeler denilebilir. Malzemenin NRC değeri 0,4 civarında ise, bu tip malzemeler için orta düzeyli ses yutucu malzeme, NRC değeri 0,3'ten azsa yansitıcı malzeme denilebilir.

Yapılan akustik ölçümler ile tabakalı yapıdaki 2. grup deney numunelerinde kullanılan ince granüllü patlamış perlit numunesinin, beklenildiği üzere $1250 \mathrm{~Hz}$ ve üzerindeki yüksek frekanslarda malzemenin ses yutum özelliğini önemli ölçüde geliştirdiği, ancak orta ve düşük frekanslarda ise mevcut ses yutum performansını azalttığı görülmektedir. NRC ölçüm hesabında kullanılan frekansların ortalaması dikkate alındığında bu durum açıkça ortaya çıkmaktadır. Nitekim ilk numune grubunun NRC değeri 0,36 iken ikinci numune grubunun NRC değeri 0,27 olarak ölçülmüştür. 
TS EN 1793-1'e göre değerlendirme yapıldığında DL $\alpha$ değeri (Tek Değerli A-Seviye Ağırlıklandırılmış Ses Basınç Seviyeleri Farkı) tek tabakalı deney numunesi grubu için 4,69 dB çıarken, iki tabakalı deney numunesi grubunda bu değer 4,95 dB olarak ölçülmüştür. (Şekil 1).

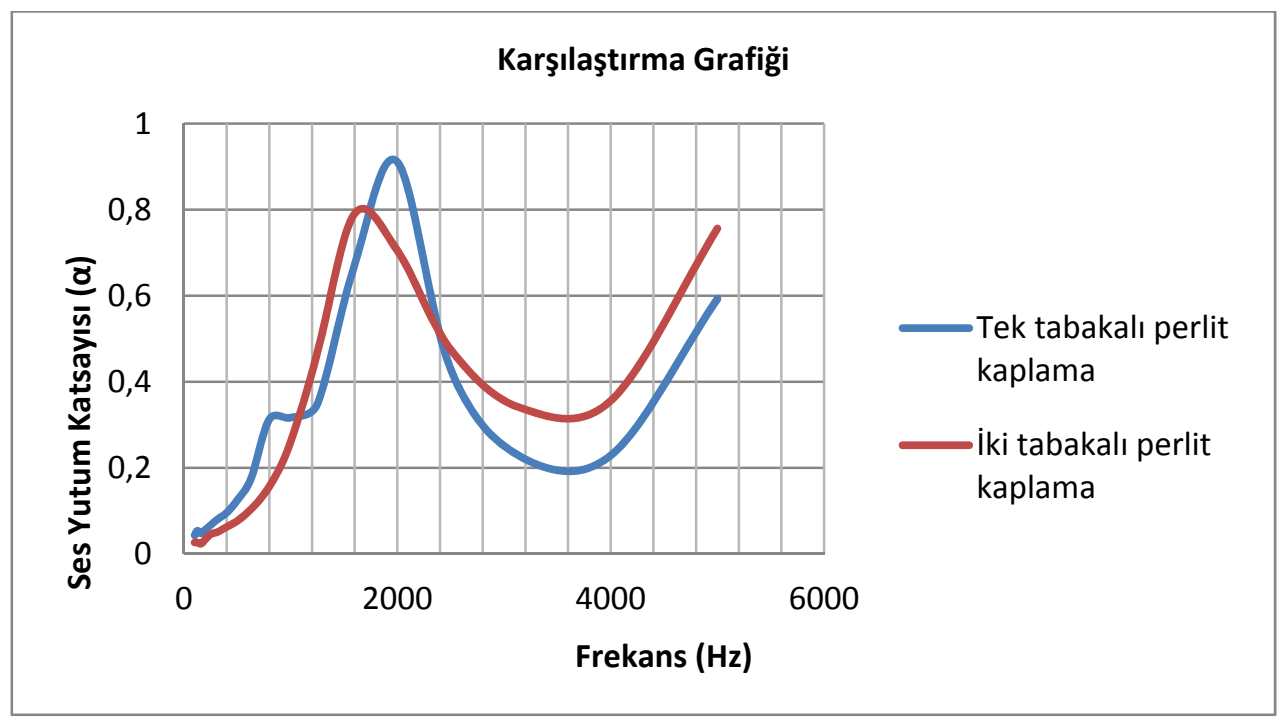

Şekil 1. Ölçüm sonuçları karşılaştırma grafiği.

TS EN 1793-1'de NRC'den farklı olarak 1/3 oktav bantlarının tüm frekanslarındaki ses yutum katsayıları dikkate alındığı için [6] iki tabakalı deney numunesinin akustik performansı daha iyi sonuçlanmıştır. Her iki deney grubu numunesi ilgili standarda göre A2 sinıfinda yer almaktadır.

\section{EKONOMIK ANALIZ}

Gürülttï bariyerlerinin inşa ve işletme maliyetleri karar vericiler için belirlenmesi gereken önemli faktörlerdir. Bunun için aşağıda açıklanan hususlar önemlidir:

-Gürültü bariyeri inşa maliyeti; projenin uygulanacağı alan ile yakından ilişkilidir. Arazi maliyeti olarak kamulaştırma maliyeti ortaya çıkmaktadır, ancak bu bedel malzeme seçiminde kullanılan karşılaştırma hesaplarında dikkate alınmamaktadır. Bunun dışında bir bariyerin inşa maliyetini sadece bariyer aks uzunluğu, yükseklik ve kalınlığı ile kullanılacak malzeme türü ile birlikte drenaj, zemin yapısı ve temel tipi, iş̧̧ilik, imalat yerine uzaklık gibi diğer etmenler de etkilemektedir. Bariyer maliyetlerinin karşılaştırılmasında en büyük problem ise bariyer inşası noktasında maliyeti etkileyen projenin uygulanacağı şehir, projenin büyüklüğü ve inşa süresi, gerekliyse kamulaştırma yapılacak arazinin değeri, inşa ve üretim sahaları arasındaki mesafe gibi birçok değişken faktörün bulunmasıdır. Dolayısıyla her projede aynı malzemeler kullanılsa dahi farklı maliyetler ortaya çıkmaktadır. Ancak bu durum ortalama bir maliyet ortaya koymaya engel değildir. Kamulaştırma gibi değişken 
kalemlerin karşılaştırma dışı tutulması ve idarelerin ortak bir karşılaştırma listesi oluşturması faydalı olacaktır.

-Bariyerin işletme maliyeti; hizmet ömrü süresince oluşan maliyetidir. Yaşam döngü maliyeti olarak da adlandırılır. Bariyerin malzeme tipi, bulunduğu iklim şartları, yüzey dokusu, rengi, diğer parçalarının birbiri ile uyumu (büzülme/genleşme gibi), yola olan mesafesi, kaza güvenliği gibi birçok faktör işletme maliyetini etkilemektedir. Tamir en büyük işletme maliyet kalemlerinden birisidir. Araçların veya araçlardan sıçrayan parçaların bariyere çarpması, bariyer inşası sırasında oluşan kusurların zamanla açığa çıkması, zamanla eskime veya kuvvetli dış etkilere maruz kalma gibi sebepler bariyer tamirini zorunlu kılmaktadır. Bakım ise eskime veya yenilenme gerektirmeden önce bariyeri koruyucu önlemlerin alınmasıdır. Özellikle boyama gibi yüzey kaplama işlemleri bakım kapsamındadır. Tamir ve bakım ile çözülemeyen problemler kısmi veya bütün olarak değiştirilme yolu ile yenilenmektedir.

Toprak sedler hariç tüm bariyerler grafitiler için boyama veya temizlenmeye ihtiyaç duyarlar. UV dayanımı düşük olan boyalı bariyerlerde yeniden boyama işlemi uygulanırken, şeffaf bariyerlerde ise parçaların değiştirilmesi söz konusudur. Kay ve diğ.'nin yaptı̆̆ı araştırmaya göre bakım maliyet hesaplarında, ortalama her 5 yılda bir kez toplam bariyer alanının \% 1 'i kadar alanın grafitiden temizlenmesi gerektiği varsayılmaktadır [7]. Aynı araştırmaya göre, beton bariyerlerin ömrü 50 yıl kabul edilerek, boya uygulanan beton bariyerlerde yeniden boyama her 20 yılda bir kez, sundurma tip boyasız beton bariyerlere estetik amaçlı boyama 25 yılda bir kez, metal bariyerlerde yeniden boyama 10 yılda bir kez yapılmalıdır. Ahşap bariyerlerin ömrü 25 yıl varsayıldığında, prekast beton paneller gibi her 10 yılda panel değişimi öngörülmektedir. Ayrıca hizmet ömrünü dolduran bariyerlerin atık maliyeti de işletme maliyeti içinde değerlendirilmektedir.

\subsection{Gürültünün Ekonomik Analizinde Kullanılan Tekniklere İlişkin Literatür}

Doğrudan ölçemediğimiz fakat etkilerini gözlemleyip yaşadığımız olguları proje fayda veya zararı olarak hesaba katmak gerekir. Gürültü de ticari olmayan olgulardandır. Ulaşım projelerinin fizibilite onay kılavuzlarında fayda maliyet analizi girdisi olarak gürültünün ekonomik değerinin dikkate alınıp alınmaması durumu ülkeden ülkeye farklılık göstermektedir. Bir ulaşım projesinde oluşan çevresel etkilerin ekonomik analizde girdi olarak kullanılmasında en çok kullanılan metot hasar fonksiyonu yaklaşımıdır (damage function approach). Çevresel etki oluşan trafik gürültüsü olarak alınırsa, şu aşamalardan oluşan bir değerlendirme işlemi yapılır [8]:

1. Proje ile oluşan gürültü emisyon değişimi yer, zaman, frekans, seviye, gürültü kaynağı tipi (birden fazla kaynak tipi de olabilir) ile birlikte tanımlanır.

2. Gürültü yayılım modelleri kullanılarak farklı noktalardaki gürültüye maruz kalma miktarı $\mathrm{dB}(\mathrm{A})$ ve gürültü indikatörleri (Ldey ve Lnight) olarak tahmin edilir.

3. Gürültü indikatörleri ile belirlenen gürültü aralıklarında, tepki (response) tipine ait "1 yılda gürültüden en fazla rahatsız olan (HA=highly annoyed) kişi yüzdesi" gibi nihai nokta belirlenir. Tepki tipine ait nihai noktalar ile maruz kalma (exposure) arasında bir bağıntı kurulur. Bu bağıntıya Maruziyet-Tepki Fonksiyonu (Exposure-Response Funtion=ERF) denir. 
4. ERF ve nihai noktalar için gerekli bilgi veri tabanı oluşturulur. Örneğin, en fazla rahatsız olan kişi sayısındaki değişimi belirleyebilmek için proje alanındaki etkilenecek bina sayısı, binalardaki daire sayıları, daire başına düşen kişi sayısı, varsa mevcut gürültü önlemleri gibi bilgilerin toplanması gerekmektedir.

5. ERF'ye ait her bir nihai noktanın bir birimlik değişiminin ekonomik değerini bulabilmek için Çevresel Değerleme Teknikleri olarak 2 ana yaklaşımdan biri kullanılır:

-Bu projeye özel temel bir çevresel değerleme tekniği olan Belirlenmiş Tercihler Tekniği,

-Mevcut değerleme çalışmalarıyla elde edilmiş tahminlerin transferi (fayda transfer teknikleri kullanımı, gürültü değerleme çalışmaları üzerine literatür veya veri tabanı taraması kullanımı gibi).

6. Ekonomik fayda/maliyet analizi ile hesaplanan gürültü rahatsızlığındaki azalma veya artışın ekonomik değeri, ilgili etkiye (örneğin; yıllık HA kişi sayısının değişim miktarı) bağlı olarak her bir nihai nokta (örneğin; Euro/HA kişi sayıs1/yıl) için hesaplanır. En sonunda ise, ERF'lere ait tüm nihai noktalardan elde edilen değerler toplanır. Yukarıda belirtilen aşamalardaki "çok fazla rahatsız olma" durumu kişiden kişiye değişen ve anketlerle belirlenen bir olgudur. Bu olgunun sosyal ve sosyo-akustik anketlerde değerlendirilebilmesi için Uluslararsı Standartlaştırma Organizasyonu (ISO) tarafından ISO/TS 15666 numaralı Teknik Şartname yayımlanmıştır [9]. Bu döküman sadece soru şekilleri, cevap ölçekleri ve sonuçların raporlanma formatını belirlemekte olup, sonuçların analizine yönelik bir $\mathrm{kural} / \mathrm{k}$ ssıt getirmemektedir. Bu teknik şartname kuralları sadece "evde" meydana gelen huzursuzluklar için geçerlidir, denilmektedir. Bu Rehbere göre gürültü rahatsılık ölçeği "kelime" esaslı cevaplar için "hiç-az-orta-çok-aşırı" olmak üzere 5, "sayısal" cevaplar için "0-10 arası" olmak üzere 11 ölçeklidir. "Çok fazla rahatsı olma (HA)” bu ölçek grubu için çok rahatsız ve aşırı rahatsız olma durumlarını kapsamaktadır [9].

Gürültü maliyetinin belirlenmesinde başlıca 3 ana başlık bulunmaktadır:

1. Kaynak Maliyeti: Genel veya özel sağlık sigortası ile doğrudan nakit olarak ödenen sağlık harcamaları bu grupta yer almaktadır.

2. Fırsat Maliyeti: İş zamanının kaybı (performans düşüklüğü nedeni ile üretkenliğin azalması durumu) veya kişisel zaman kaybının (ödemesi olmayan iş dahil fazla çalışma durumundan dolayı kişisel zaman kaybı) maliyeti bu grupta yer almaktadır.

3.Yararsızlık (Dis-utility) Maliyeti: Gürültü nedeni ile kişisel zaman tatminindeki azalma, konforsuzluk veya rahatsızlık, ağrı ve keder, gelecek hakkında ümitsizliğe düşme, aile fertlerine veya başkalarına rahatsızlık verme vb.durumları ele alınmaktadır.

İlk iki madde genel olarak hastalıktan sakınma maliyeti (Cost-of-Illness COI) olarak adlandırılmaktadır. Ulaşım gürültüsünün değerlemesinde genellikle gürültüden duyulan rahatsızlığın kendisi dikkate alınır. Sağlık üzerindeki etkisi veya uyku üzerindeki etkileri kimi zaman dikkate alınırken, algı ve iletişim üzerindeki etkisi ise hiç dikkate alınmamaktadır. Ayrıca bu değerlemede okul, ofis, fabrika gibi alanlarda değil, sadece "konutlarda" meydana gelen trafik gürültü rahatsızlığı hesaba katılmaktadır. Gürültü değerlemesi üzerine büyük etkisi olmasa da, Avrupa'da sadece Fransa ve Danimarka'da gürültünün sağlık üzerindeki etkisi dikkate alınmaktadır [10]. 


\subsubsection{Karayolu Kaynaklı Gürültüyü Değerleme Teknikleri}

Otoyol kenarında yaşayan insanların otoyoldan kaynaklanan gürültüden ne kadar etkilendiği akustik ölçümler veya modeller yardımı ile bulunabilir veya tahmin edilebilir. Oluşan etki fayda-maliyet analizine dönüştürülmek istenildiğinde ise farklı birimlerdeki farklı olguların birlikte nasıl değerlendirileceği problemi ortaya çıkmaktadır. Böyle bir çalışmada tüm girdiler ve çıktıların, fayda ve maliyet olarak değerlemesinde, aynı birime dönüştürülmesi gerekir. Tüm soyut ve somut olguları, oluşan gürültünün yaptığı etkiyi de parasal olarak dönüştürmek gerekmektedir. Literatürde çok farklı çevresel değerleme sınıflandırmaları bulunsa da genel olarak doğrudan (belirlenmiş tercihler) ve dolaylı (önceki çalışma sonuçlarının transferi) metodlar olarak ayrılabilir.

\section{Açıklanmış Tercihler (stated preferences-sp) Teknikleri}

Açıklanmış tercihler tekniği daha çok piyasa araştırması için kullanılmak amacı ile 1970lerde geliştirilmiştir. Doğrudan ölçüm metodlarından olup, daha çok anket çalışmasına dayalı çalışmalardır. Anket yapılan grup veya topluluğun sorulan sorular karşısında verdiği cevaplara göre herhangi bir mal veya hizmet için en fazla ne kadar ödeyebileceklerinin belirlenmesine yönelik yöntemler grubudur. Bu teknikte en çok kullanılan soru tarzı, belli parametrelerle (ulaşım modu-para-zaman gibi) karşılaştırmalı olarak verilen iki durum karşısında anket grubunun hangisini seçeceğini kesinlik derecesine göre belirlemesi şeklindedir. Kesinlik derecesi "kesinlikle A/B", "belki A/B" veya "A ve B arasında kararsız" gibi sunulan seçeneklerin anket grubu tarafından işaretlenmesi şeklinde belirlenmektedir. Açıklanmış tercihler metodunun dezavantajlarından biri de verilen cevapların doğruluğudur. Nitekim verilen cevapların ne kadar sağlıklı olduğunun kimi zaman başka metotlarla doğrulanması gerekebilir [11].

\section{Belirlenmiş Tercihler Teknikleri}

Koşullu Değerleme Yöntemi (contingent valuation method-CVM): Doğrudan ölçüm yaklaşımı ile anket grubuna kazanacakları bir fayda için doğrudan ödemek istedikleri vergi veya ödeme şeklinde belirtilmiş tutarın (Ödeme İstekliliği veya WTP-willingness to pay) veya kaybedecekleri bir fayda için kabul edecekleri kendilerine yapılacak ödemenin (Kabul İstekliliği veya WTA-willingness to accept) sorulması ile gerçekleştirilen çalışmadır. Soruların önyargıdan uzak hazırlanması gerekir ve anket yapılan kişileri mümkün olduğunca tanıyabilme imkanı sunmalıdır. CVM'nin en önemli dezavantajı ödeme istekliliği her zaman ödeyebilme gücü anlamına gelmemektedir. Burada dikkat edilecek diğer bir husus da protesto amacı ile verilen aykırı değerlerdir. Belli bir alan dışında kalan aykırı sonuçlar değerlendirme dışına alınmalıdır.

Tercih Modellemesi (choice modelling): Ankete katılanların belli alternatifler arasında seçim yapması talep edilir. Her bir alternatifin altında o alternatife ait tanımlayıcı ve/veya ayırt edici nitelikler bulunmaktadir. Bu nitelikler en fazla 4-5 adet kadar olup, anket grubundan bu alternatifler arasından en çok hangisini diğerlerine tercih ettiğini belirlemek üzere sıralama yapması istenir. Tüketici bu durumda tercihini ayrı ayrı özelliklerin değerlendirilmesi olarak değil, tüm özelliklerin birarada olduğu bir paket olarak gerçekleştirmiş olur. 


\section{Ortaya Çıkan Tercihler (revealed preferences-RP) Teknikleri}

Belirlenmiş teknikler metodundaki gibi kuramsal bir alan üzerinde soru sorma şeklinde değil, gerçekleşen tercih ve olayların gözlemlenmesi esasına dayanmaktadır. Kısaca dolaylı ölçüm teknikleridir. $\mathrm{Bu}$ tekniklerde piyasadaki tüketicilerin gerçekleştirdikleri davranışlardan, fayda olarak kazanacakları bir hizmete ne kadar ödeyebilecekleri tahmin edilmeye çalışılır. En çok kullanılan RP teknikleri şunlardır:

Hedonik Ücretleme Yöntemi (hedonic pricing method-HPM): Büyüklük, yap1, tasarım gibi aynı fiziksel özelliklere ait iki ev arasında dahi fiyat olarak fark olabilir. Bunun nedeni ulaşım modlarına yakınlık, aydınlanma oranı, işe yakınlık, manzara gibi diğer etmenlerdir. $\mathrm{Bu}$ durumda tüketiciler bu çevre şartları için ne kadar fazla ödeyebileceklerine karar vermektedirler. Hedonik Yaklaşım bu farkı belirlemeye yönelik bir tekniktir. Değerlendirme olarak denge durumundaki bir piyasadaki konut fiyatlarını dikkate alır.

Seyahat Maliyeti Yöntemi (travel cost method-TCM): Genellikle seyahat ve dinlence hizmetlerinin değerini ölçmek için kullanılan bir metodtur. Seyahat zamanı ve araç kullanımından kaynaklanan maliyetler, genel maliyetler arasında yer almalıdır. Seyahat zamanını maliyet olarak dönüştürürken genellikle birim zaman çalışma maliyeti dikkate alınmaktadır, ancak insanlar çalışma saatleri içerisinde bu tip seyahatler yapmamaktadır. Ayrıca sigorta ve amortisman giderleri bazı değerlendirmelerde yakıt gideri ile birlikte dikkate alınmamaktadır. Bu belirsizlikler, örneğin çalışma saati birim ücretinin \%50sinin veya $1 / 3$ ünün birim saat maliyeti olarak dikkate alınması gibi belli kabuller ile aşılmaktadır. Dikkat edilmesi gereken diğer bir husus ise gerçekleştirilen seyahatin bir amaç için gerçekleştiriliyor olmasıdır. Aksi takdirde maliyetlerin amaçlar arasında bölüştürülmesi gerekir.

Fayda Transfer Yöntemi (benefit transfer method-BT): Piyasada bulunmayan bir ürün veya gerçekleşmemiş bir faaliyet için yapılan öngörü metodlarındandır. Farklı bir lokasyon ve şartlarda gerçekleşmiş ürün veya hizmetin, bulunulan konuma transfer edilmesi ile sonuçların öngörülmeye çalışılmasıdır. Anket çalışmalarının uzun zaman alması ve maliyetli olmasından dolayı oldukça faydalı bir yöntemdir. Fayda transfer yönteminde ise 2 ana yaklaşım mevcuttur.

\section{- Tekil Değer Transfer Metodu (basit yöntem)}

-Basit Birim Transferi: Fayda transferindeki en kolay yöntem olup, daha önce yürütülen bir çalı̧̧ma alanından elde edilen ortama fayda (utility) veya kullanılmazlık (dis-utility) değerinin aynı mevzuata tabi olan alan içerisinde ortalama değer olarak kullanılmasıdır.

-Birim Transferi (gelir düzeltme faktörü ile): Eğer tahmini fayda birimi örneğin "Euro/dB/kişi/yll" ise, aynı politik alan içerisinde olsa bile kişilerin $1 \mathrm{~dB}$ değişim için verecekleri rahatsızlık tepki düzeyi birbirinden farklı olacaktır. Bunun ilk nedeni gelir, din, eğitim düzeyi, sosyo-ekonomik durum vb. farklılıklar iken diğer nedeni ise, insanların gürültüden kaçınmak için aynı şartlara sahip olmamalarıdır. Eğer tahmini fayda birimi örneğin "Euro/rahatsız olan kişi sayısı/yıl" şeklinde düzenlenirse, bu kısıtlara takılmadan değerlendirme yapma imkanı oluşacaktır. Ancak ülkeler arasında basit birim transfer metodu doğrudan kullanılmamalıdır. Satınalma gücü paritesi (PPP) indeksi gibi bir karşılaştırma ile birim transfer değeri üzerinde gelir düzeyi düzeltmesi yapılmalıdır. Her ne kadar gelir düzeyi 
dikkate alınsa da din, kültür, eğitim düzeyi gibi daha önce sayılan birçok parametre bu dönüşümde kullanılmamaktadır.

- Fonksiyon Transfer Metodu

-Fayda Fonksiyon Transferi: Fayda değerinin kendisinin transfer edilmesindense fayda değerinin bulunmasında kullanılan fonksiyonun transfer edilmesi metodudur.

-Meta Analizi: Sadece bir değerleme sonucunda elde edilen fayda fonksiyonunun transferindense, birçok değerleme çalışmasının sonucundan ortak bir fayda fonksiyonunun tahmin edilmesi metodudur.

\subsubsection{Gürültü̈ Bariyeri için Fayda /Maliyet Analizi}

Fayda-maliyet analizi (FMA), proje ömrü boyunca projedeki indirgenmiş girdilerin, diğer bir ifade ile kazanımların projenin indirgenmiş çıktılarına oranlanmasıdır. Girdi ve çıktılar yıllara sari olarak işlem gerektiriyorsa, tüm değerlerin bugünkü değerlere eşitlenmesi gerekmektedir (Bağıntı 2).

$F / M=\sum_{t=0}^{m+n} \frac{F_{t}}{(1+i)^{t}} / \sum_{t=0}^{m+n} \frac{M_{t}}{(1+i)^{t}}$

F: Fayda, M: Maliyet, Ft: Projenin t yılındaki faydalar, Mt: Projenin t yılındaki maliyetler, m: Proje inşa süresi, n: Projenin ekonomik ömrü, i: Gerçek faiz oranı (Real Interest Rate) veya indirgeme oranıdır. "i" ile verilen gerçek faiz oranı piyasadaki faiz oranı kavramından farklıdır.

Piyasada kullanılan faiz oranı 3 ana bileşenden oluşmaktadır;

•Enflasyon bileşeni: Bu bileşen alım gücündeki azalmayı göstermektedir.

-Risk bileşeni: Bu bileşen borcun geri ödenmemesi durumundaki riski ifade etmektedir.

-Gerçek faiz oranı: Risksiz faiz de denilen, paranın üretim değerini gösteren ve enflasyon bileşeninden bağımsız genellikle devlet tahvil ve bonosu faiz oranlarından enflasyon oranının çıkarılması ile elde edilen birleşendir.

İndirgeme oranını belirleyen unsurlar şunlardır;

-Borç alınan finansman kaynakları için ödenen faiz oranları

-Sermaye piyasasında geçerli olan faiz oranları (mevduat faizi, bono faizi vb).

-Benzer yatırım konularındaki kârlılık oranları.

Dış borçlanma, özkaynaklar, ticari kredi gibi birden fazla kaynak kullanılıyor ise, birden fazla indirgeme oranı bulunup, bunların ağırlıklı ortalaması alınarak tek bir indirgeme oranı elde edilmektedir. Birçok çevre ekonomisti, fiyatların başlangıç yılına veya istenilen bir tarihe indirgenmesinde kullanılan ve indirim oranı (i) olarak verilen değerin hesaplarda kullanılmamasını veya çok düşük bir değer olarak ele alınması gerektiğini ifade etmektedir. 
Bir projenin yatırım yapılabilir nitelikte olup olmamasında sadece F/M analizi kullanılmaz. Fizibilite çalışmalarında genellikle belli bir tarihe indirgeme tekniğine dayanan aşağıdaki metotlar da kullanılmaktadır; [12]

- Net Bugünkü Deger (net present value) (NBD-NPV)

- İç Kârlılık Oranı (internal rate of return) (IKO-IRR)

- Fayda/Maliyet Oranı (benefit/cost ratio) (F/M-B/C)

- Geri Ödeme Süresi (payback period).

Avrupa'da gürültü bariyerlerinin ekonomik anlamda yatırım yapmaya değer olup olmadığının karar verilmesinde genel olarak proje analiz tekniklerinden biri olan FMA kullanılmaktadır [13]. Bir gürültü bariyeri için fayda maliyet analizi için fayda ve maliyet olarak temel girdiler şu şekilde özetlenebilir;

Maliyetler (bariyer inşa ve işletme maliyeti): Bariyerin inşa süresince harcanacak tüm kalemlere ait maliyetler ile bariyerin hizmet ömrü boyunca gerektirdiği bakım, onarım, yenileme gibi her türlü işletme maliyetini içermektedir. Genellikle sadece bu iki maliyet türü FMA'nin maliyet kısmı için kullanılmaktadır. Belirlenen servis ömrü için bu aşamada kaplamalı ve kaplamasız beton bariyer tipleri için belirlenen literatür ömrüne göre (50 yıl), 1 km uzunluğunda inşa edilen bir gürültü bariyerinin hizmet ömrü boyunca meydana gelecek tamir bakım ve onarım giderleri işletme gideri olarak hesaplanarak, bugünkü değer (PW=Present Worth) cinsinden Bağıntı (3) kullanılarak [14] güncellenmektedir.

$$
P W=I C C+\sum_{k=1}^{n} F C\left[\frac{1}{(1+i)^{n}}\right]
$$

PW: Bugünkü değer (Present Worth), ICC: Başlangıç inşa maliyeti (Initial Construction Cost), FC: Bakım giderleri (Future Costs), n: Hizmet ömrü (Number of years), i: İndirgeme oranidir.

Gürültü bariyerleri bakım giderleri için gereken malzeme ve iş gücü birim fiyatları Çevre ve Şehircilik Bakanlı̆̆ı'nın yayınladığı pozlardan alınmıştır. Türkiye'de bariyer kullanımının henüz yaygınlaşmaması ve bu konuda bir veri tabanının olmamasından dolayı hesaplamalarda kullanılacak değişim, bakım gibi işlem sıklıkları için ise aşağıdaki kabuller dikkate alınacaktır [14];

-Değiştirme: Her 10 yllda 1 kez toplam bariyer uzunluğunun \%1'inin değiştiği varsayılmaktadır.

- Genel Boyama: Grafiti (duvar yazıları) önleyici olarak uygulanan boyama aşamasıdır. Her 5 yılda $1 \mathrm{kez}$ bariyer toplam alanının \%1'inin boyandığı varsayılmaktadır.

-Koruyucu Boyama: Kendiliğinden desenli veya dokulu beton yüzeyler için boyama gerekmemektedir, ancak bariyer ömrünün yarısında (genellikle 25 yıl) bunların boyandığı varsayılır. Genel anlamda boyanan beton yüzeyler için boyama sıklığı 20 yıldır. Metal yüzeyler için ise 10 yıl dikkate alınmaktadır.

- Çim Biçme ve Arazi İşleri: Sadece toprak sed bariyerler için geçerlidir. Yıllık olarak gerçekleştirilmektedir. 
Faydalar (akustik konfor kazanımları): Bariyerin işletme ömrü boyunca, bariyerin konumlanması nedeni ile akustik olarak çevresel gürültü düzeyinde bir azalma meydana gelecektir. İletişimde anlaşılabilirlik, gürültü nedeni ile tetiklenen stres ve kalp rahatsılıklarında azalma, ev içi akustik yaşam kalitesinin artması, dinginlik, eğitim veriminin artması, gürültü kaynaklı uykusuzluk problemlerinde azalma gibi akustik konforun getireceği birçok fayda bulunmaktadır. Bu faydaların parasal karşılığının bulunmasında daha önce de bahsedilen gürültünün ekonomik değerlenmesi metodlarından biri kullanılmaktadır.

Çalışmada Türkiye'deki gürültünün ekonomik analizi için ülke bazında bir çalışma yapılmadığından Avrupa Birliği ülkeleri tarafından Avrupa geneli için yapılan çalışma ve kabuller ile Fayda Transfer (BT) Metodu kullanılacaktır. Avrupa'da gürültüden rahatsız olan insan sayısını bulmak için genellikle Lgag kullanılmaktadır [7]. Gürültüden etkilenme oranı da her gürültü seviyesi için insanlar arasında farklılık göstermektedir. Bu nedenle öncelikle rahatsız olma miktarını gruplayarak tanımlamak gerekmektedir. Dünya Sağlık Örgütü-WHO [15], çevresel etki değerlemesinde kullanılan "rahatsızlık (annoyance)" kavramının tanımını "bir gürültü ile başlatılmış hoşnutsuzluk hali" olarak tanımlamaktadır. Bu hoşnutsuzluk halini ülkeler farklı kategorize etmektedirler, ancak genel olarak "az rahatsız", "rahatsız" ve "aşırı rahatsız" olarak 3 seviyede değerlendirilir.

Aşırı rahatsız olan kişiler genellikle yüksek gürültü seviyelerine maruz kalan ve bu gürültü sebebi ile gece uykudan uyanan, kan basıncı yükselen ve kalp rahatsızlığı bulunan kişilerdir. Aşağıda Lgag gürültü seviyesine maruz kalan kişiler üzerinde oluşan rahatsılılı üzerine yapılan bir çalışmada kullanılan formül bulunmaktadır [16]. Burada anket çalışması Avrupa, Kuzey Amerika ve Avustralya bölgelerini kapsayacak şekilde gerçekleştirilmiştir. Bu çalışmada Miedema ve diğ. aşağıdaki modelleri kullanmışlardır, (Bağıntı 4 ve 5):

$$
\begin{aligned}
& \% A=1,795 * 10^{-4}\left(L_{g a g}-37\right)^{3}+2,11 * 10^{-2}\left(L_{g a g}-37\right)^{2}+0,5353\left(L_{g a g}-37\right) \\
& \% H A=9,868 * 10^{-4}\left(L_{\text {gag }}-42\right)^{3}+1,436 * 10^{-2}\left(L_{\text {gag }}-42\right)^{2}+0,5118\left(L_{\text {gag }}-42\right)
\end{aligned}
$$

\%A: Rahatsız kişi yüzdesi (\% Annoyed) ve \%HA: Aşırı rahatsız kişi yüzdesi (\% Highly Annoyed).

\subsection{Yapılan Modellemeye Göre Rahatsızlık Analizi}

Perlitli kaplamanın sağlayacağı gürültü azaltım değerini belirleyebilmek için Datakustik Firmasına ait ve Avrupa Birliği Komisyonu tarafından sonuçları Birlik Ülkelerinde geçerli kabul edilen CadnaA adlı gürültü haritalama yazılımı vasıtasıyla örnek bir alanda modelleme işlemi gerçekleştirilmiştir [28].

Tezde yapılan ayrıntılı çalışmada mevzuata göre sınır değer üzerinde kalan kişi sayıları hesaplanmıştır, ancak insanların gürültü seviyelerine karşılık gelen rahatsızlık durumları birbirinden farklı olduğu için Miedema ve diğ.'nin yukarıda verilen modeli kullanılarak rahatsızlık analizi yapılmıştır. 
Çizelge 2. Rahatsızlık analizi sonucu rahatsız ve aşırı rahatsız kişi sayıları tablosu.

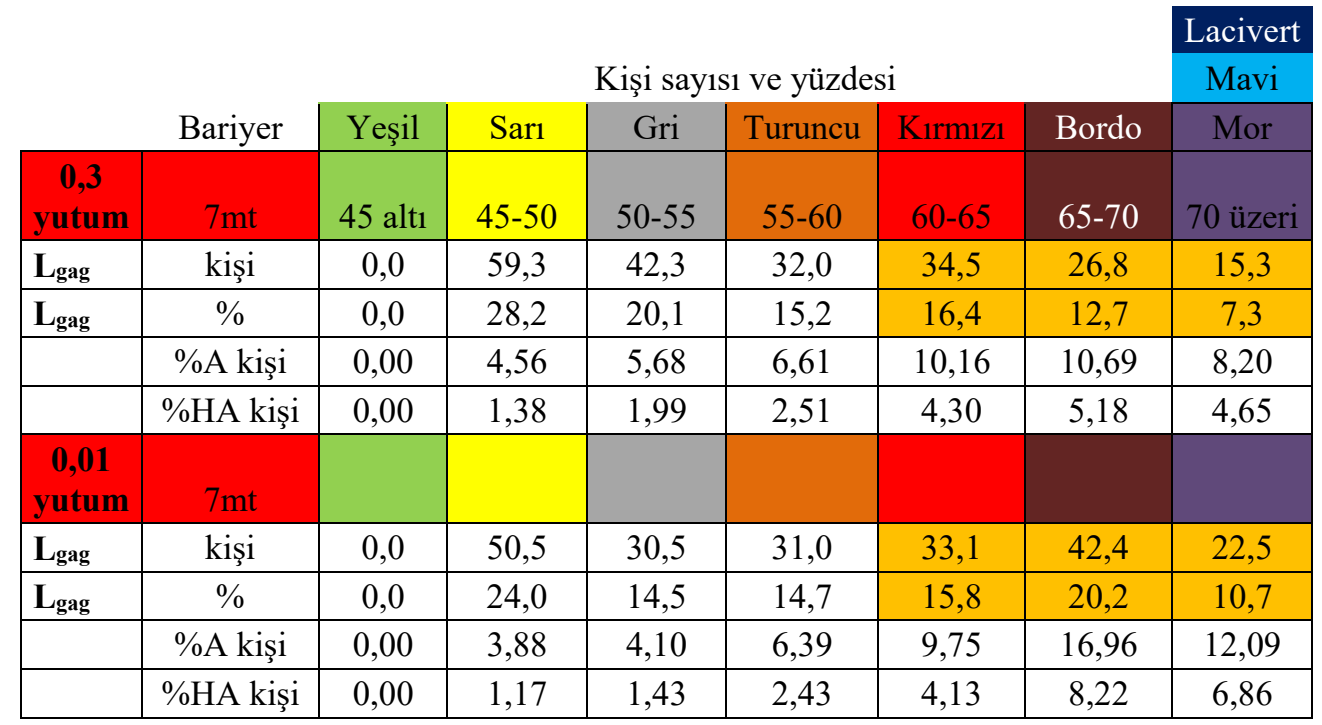

Çizelge 3. Rahatsızlık analizine göre limit gürültü değerleri üzerinde etkilenen kişi sayısı.

\begin{tabular}{|c|c|c|c|c|}
\hline Bariyersiz Durum & Kişi sayısı & $\%$ nüfus & Toplam kişi & Toplam \%* \\
\hline $\begin{array}{l}\text { Lgag sınır değerine } \\
\text { göre } \geq 63,2 \mathrm{~dB}(\mathrm{~A})\end{array}$ & 149 & $\% 70,7$ & 149 & $\% 70,7$ \\
\hline Lgag $\% A$ & 72 & $\% 34,4$ & \multirow{2}{*}{109} & \multirow{2}{*}{$\% 51,9$} \\
\hline Lgag \%HA & 37 & $\% 17,5$ & & \\
\hline $\begin{array}{l}7 \mathrm{mt} \text { Yansitıcı } \\
\text { Beton Bariyer }\end{array}$ & Kişi sayısı & $\%$ nüfus & Toplam kişi & Toplam \% \\
\hline $\begin{array}{l}\text { Lgag sınır değerine } \\
\text { göre } \geq 63,2 \mathrm{~dB}(\mathrm{~A})\end{array}$ & 82 & $\% 38,8$ & 82 & $\% 38,8$ \\
\hline Lgag \%A & 53 & $\% 25,3$ & \multirow{2}{*}{77} & \multirow{2}{*}{$\% 36,8$} \\
\hline Lgag \%HA & 24 & $\% 11,5$ & & \\
\hline $\begin{array}{l}7 \text { mt Perlit } \\
\text { Kaplamalı Yutucu } \\
\text { Beton Bariyer }\end{array}$ & Kişi sayısı & $\%$ nüfus & Toplam kişi & Toplam \% \\
\hline $\begin{array}{l}\text { Lgag sınır değerine } \\
\text { göre } \geq 63,2 \mathrm{~dB}(\mathrm{~A})\end{array}$ & 59 & $\% 28,2$ & 59 & $\% 28,2$ \\
\hline Lgag \%A & 46 & $\% 21,9$ & \multirow{2}{*}{66} & \multirow{2}{*}{$\% 31,4$} \\
\hline Lgag \%HA & 20 & $\% 9,5$ & & \\
\hline
\end{tabular}


Diğer bir ifade ile, mevzuatta verilen limite göre görece olarak daha düşük gürültü seviyesine maruz kalan insanlar da aşırı rahatsız veya rahatsız olabilirler. $\mathrm{Bu}$ durum limit değerlerden bağımsız olarak hesaplanmaktadır.

Rahatsızlık analizi 7m yüksekliğindeki perlit kaplamalı ve yansıtıcı bariyerlerden elde edilen

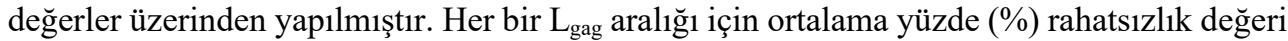
yeniden hesaplanmıştır (Çizelge 2-3). Tabloda $7 \mathrm{~m}$ perlit kaplamalı gürültü bariyeri için yapılan incelemeden $\mathrm{L}_{\text {gag }}$ sınırı üzerinde kalan sayısından daha fazla sayıda kişinin rahatsız ve aşırı rahatsız kişi toplamına sahip olduğu görülmektedir. Bunun nedeni Miedema ve diğ. çalışmasında bu değerin $45 \mathrm{~dB}(\mathrm{~A})$ gibi daha düşük gürültü seviyeleri için de hesaplanıyor olmasidir [16].

\subsection{Gürültü Modelleme Sonucuna Göre Perlitli Kaplamanın Ekonomik Analizi}

Gürültü bariyerlerinin inşasında karar vericiler açısından fizibilite anlamında değerlendirmeye alınabilecek çok fazla sayıda parametre bulunmamaktadır. Özellikle fayda kısmında sadece bariyer konumlandırılması sebebi ile oluşan gürültü azalması yer almaktadır. Bu da ekonomik olarak parasal bir değere dönüştürüldüğünde, etkilenen kişi sayısına bağlı olarak, genellikle büyük maddi karşılığı ortaya çıkmamaktadır. Bu nedenle birçok gürültü bariyeri projesi tek başına ekonomik anlamda yatırım yapılabilir nitelikte değildir. Gürültü bariyerleri genellikle yeni bir otoyol inşası gibi büyük projelerin içerisinde toplam fayda ve maliyetler içerisinde değerlendirilmektedir. Mevcut yollar ve yapılar için ise genellikle mevzuatın istediği değerleri sağlayabilmek ve çevrede yaşayan insanların hem akustik hem de psikolojik anlamda rahatlaması adına yatırım yapılabilirliğine bakılmaksızın sosyal sorumluluk gereği yerel yönetim ve otoyol idareleri tarafından inşa olunmaktadır. Ancak bu ekonomik değerlendirme yöntemleri, gürültü bariyerleri için yatırım yapılabilir çıkmasa bile, birden fazla seçenek arasından en ekonomik çözümün bulunmasında da kullanılmaktadır.

Beton gürültü bariyerleri bilindiği üzere, çevre şartlarına en dayanıklı bariyer tiplerindendir. Ayrıca diğer bariyer türlerine göre daha az bakım maliyetine sahiptirler. Beton gürültü bariyeri üzerine perlitli kaplama uygulaması gerçekleştirildiğinde elde edilecek kazanımlar fayda ile ifade edilecektir. Ekonomik fizibilite etüdünde, proje konusu olan perlit esaslı gürültü bariyer kaplamasının yapılması durumunda ortaya çıkacak faydalar ve maliyetler genel ekonomi açısından değerlendirilmiştir. Bu amaçla, göz önüne alınan değerlendirme dönemi içinde, projenin yapılması (perlit kaplamalı gürültü bariyeri inşası) ve yapılmaması (perlit kaplamalı olmayan normal betonarme gürültü bariyeri inşası) durumlarındaki ekonomik maliyetler göz önüne alınarak, projenin yapılmasıyla ekonomik maliyetlerde ortaya çıkacak azalmalar projenin net faydası olarak hesaplanmıştır. Ekonomik değerlendirmede, projenin ekonomik net güncelleştirilmiş değeri (NPV, net present value), ekonomik iç verimlilik oranı (EIRR, economic internal rate of return) ve fayda / maliyet oranı (B/C, benefit /cost ratio) hesaplanmıştır. 
Tabloda (4) yutucu ve yansıtıcı bariyer tiplerinde hesaba katılan inşa ve işletme kalemleri ayrı ayrı gösterilmiştir. Bariyeri perlit kaplamanın maliyeti hesaplanırken, kaplama maliyeti ve gerektirdiği bakım işlemi maliyetinden, bu kaplamanın yapılması dolayısı ile yapılmayacak olan, genel boyama işlemi gibi yansıtıcı beton bariyere ait bazı işlem maliyetleri çıkarılmıştır. Yansıtıcı beton gürültü bariyer inşa maliyeti için bariyere ait detaylı bir proje yapılmamış olup, Bakanlık tarafından yayımlanan yapı yaklaşık maliyetleri üzerinden benzeşim yapılarak, dikkate alınmış ve hesaplanmıştır. Tezde belirlenen bariyer uzunluğu $80 \mathrm{~m}$ dir. Yapılacak maliyet hesapları $80 \mathrm{mlik}$ bariyer üzerinden gerçekleştirilmiştir. Maliyetler 2015 yılı sabit fiyatları ile Amerikan Doları (\$) cinsinden hesaplanmıştır. TL (Türk Lirası) olarak hesaplanan değerler, T.C. Merkez Bankası 2015 yılı aylık ortalama dolar kuru üzerinden hesaplanarak, yıllık ortalama yaklaşık $1 \$=2,73$ TL dolar kuru esas alınarak dolar değerine dönüştürülmüştür. Aynı şekilde Euro/Dolar paritesi 2015 yılı için ortalama 1,11 olarak hesaplanmıştır [17].

Çizelge 4. Inşa ve işletme maliyetleri genel karşılaştırma ve işlem sıklı̆̆ tablosu.

\begin{tabular}{|c|c|c|c|c|}
\hline \multirow{2}{*}{ İnşa ve işletme listesi } & \multicolumn{2}{|r|}{ İşlem S1klığ1 } & \multirow{2}{*}{$\begin{array}{l}7 \mathrm{mt} \text { Yansitıcı } \\
\text { Beton Bariyer }\end{array}$} & \multirow{2}{*}{$\begin{array}{l}7 \mathrm{mt} \text { Perlit Kaplamalı } \\
\text { Yutucu Beton Bariyer }\end{array}$} \\
\hline & İNŞA & BAKIM & & \\
\hline Bariyer İnşa Maliyeti & $1 \mathrm{kez}$ & - & $\checkmark$ & $\checkmark$ \\
\hline Kaplama İnşa Maliyeti & $1 \mathrm{kez}$ & - & - & $\sqrt{ }(+)$ \\
\hline Bariyer kısmi değişimi & - & $\begin{array}{c}10 \text { yilda } 1 \mathrm{kez} \\
\text { Bariyer uzunlunun } \\
\% 1 \text { 'i kadar }\end{array}$ & $\checkmark$ & $\checkmark$ \\
\hline $\begin{array}{l}\text { Kaplama kısmi } \\
\text { değişimi }\end{array}$ & - & $\begin{array}{c}\text { Yilda } 1 \mathrm{kez} \\
\text { Bariyer uzunlunun } \\
\% 5^{\prime} \text { 'i kadar }{ }^{1}\end{array}$ & - & $\checkmark(+)$ \\
\hline Bariyer genel boyama & - & $\begin{array}{c}20 \text { yılda } 1 \mathrm{kez} \\
\text { Bariyer alanının } \\
\text { tamamı }\end{array}$ & $\sqrt{ }(-)$ & - \\
\hline Kaplama genel boyama & - & - & - & - \\
\hline $\begin{array}{l}\text { Bariyer koruyucu } \\
\text { boyama (grafiti gibi) }\end{array}$ & - & $\begin{array}{c}5 \text { yılda } 1 \mathrm{kez} \\
\text { Bariyer alanının \%1'i } \\
\text { kadar }\end{array}$ & $\sqrt{ }(-)$ & - \\
\hline $\begin{array}{l}\text { Kaplama koruyucu } \\
\text { boyama (grafiti gibi) }{ }^{2}\end{array}$ & - & - & - & - \\
\hline $\begin{array}{l}\text { Kaplama tıkanıklık } \\
\text { temizliği (vakumlu } \\
\text { süpürge) }\end{array}$ & - & Her y1l 2 kez & - & $\checkmark(+)$ \\
\hline $\begin{array}{l}\text { Bariyer çevresi } \\
\text { temizliği }\end{array}$ & - & 5 yilda $1 \mathrm{kez}$ & $\checkmark$ & $\checkmark$ \\
\hline \multicolumn{5}{|c|}{$\begin{array}{l}{ }^{1} \text { Literatürde yer alamayan, tasarlanan perlitli kaplama malzemesine ait kabul } \\
{ }^{2} \text { Kendiliğinden desenli veya dokulu yüzeyler için koruyucu boyama gerekmemektedir. } \\
{ }^{3} \text { Yıkama yapılması durumunda tıkanıklık zamanla daha fazla ve kalıcı hale gelmektedir. Bu nedenle vakumlu } \\
\text { temizleme yöntemi seçilmiştir. } \\
(+) \text { Maliyet toplamı girecek kalemler }\end{array}$} \\
\hline
\end{tabular}




\subsubsection{Fayda Hesabı}

Perlit kaplama işleminin gerçekleşmesi öncesinde ve sonrasında rahatsız olan ve aşırı rahatsız olan toplam kişi sayıları arasındaki fark perlit kaplamanın akustik olarak ne kadar kişiyi rahatsız olma durumundan kurtardığına dair bir göstergedir. Bu ifade "para birimi”/“(aşırı) rahatsız olan kişi sayısındaki değişim"/“süre" olarak verilmektedir. Buradaki fayda hesabında perlitli kaplama yapılması öncesinde ve sonrasında "(aşırı) rahatsız olan kişi”" sayıları arasındaki fark, daha önce verilen rahatsızlık analiz sonuçları ile limit gürültü değerleri üzerinde etkilenen kişi sayısı karşılaştırma tablosundan elde edilmiştir, Çizelge 5.

Çizelge 5. Rahatsızlık analizine göre limit gürültü değerleri üzerinde etkilenen kişi sayısı farkı

\begin{tabular}{|c|c|c|c|}
\hline Kişi sayısı & $\begin{array}{l}7 \mathrm{mt} \text { Yansitıcı } \\
\text { Beton Bariyer }\end{array}$ & $\begin{array}{l}7 \mathrm{mt} \text { Perlit Kaplamalı } \\
\text { Yutucu Beton Bariyer }\end{array}$ & $\begin{array}{c}\Delta \text { Fark } \\
\text { (kişi sayısı) }\end{array}$ \\
\hline $\begin{array}{l}\text { Lgag sınır değerine göre } \\
\geq 63,2 \mathrm{~dB}(\mathrm{~A})\end{array}$ & 82 & 59 & 23 \\
\hline Lgag \%A & 53 & 46 & 7 \\
\hline Lgag \%HA & 24 & 20 & 4 \\
\hline Lgag $\%$ НА $\%$ \% & 77 & 66 & 11 \\
\hline
\end{tabular}

Avrupa 6. Çerçeve Programında 2002-2006 yılları arasında tamamlanan HEATCO (Developing Harmonised European Approaches for Transport Costing and Project Assessment) Projesinde ise gürültü rahatsızlık seviyesine göre elde edilen parasal değerler Çizelge 6'da verilmektedir [18].

Çizelge 6. Karayolu gürültüsü için önerilen ekonomik değer tablosu.

\begin{tabular}{|l|c|c|}
\hline \multicolumn{1}{|c|}{ Rahatsızlık Kategorisi } & $\begin{array}{c}\text { Euro/rahatsız kişi/yıl (2006 } \\
\text { yılı) }\end{array}$ & $\begin{array}{c}\text { Euro/rahatsız kişi/yıl } \\
\text { (2015 yılı güncelleme) }\end{array}$ \\
\hline $\begin{array}{l}\text { Aşırı Rahatsız (Highly } \\
\text { Annoyed) }\end{array}$ & 85 & 104 \\
\hline Rahatsız (Annoyed) & 85 & 104 \\
\hline Az Rahatsız (Little Annoyed) & 37 & 45 \\
\hline Rahatsız Değil (Not Annoyed) & 0 & 0 \\
\hline $\begin{array}{l}\text { * Avrupa Merkez Bankası verilerine göre 2006-2015 yılları arası ortalama enflasyon oranı yaklaşı \%2,0 olarak } \\
\text { alınmıştır [19]. }\end{array}$ \\
\hline
\end{tabular}

Verilen değerin doğrudan kullanılmasındaki sakıncadan dolayı Avrupa genelinden elde edilen tekil değerin transferinde Gayrisafi Yurtiçi Hasıla (GYİH) oranları kullanılarak bu değer Türkiye için adapte edilmiştir. Avrupa Birliğinin satınalma gücü paritesinden (PPP) elde edilen GYİH 2015 yılı değeri ve Türkiye'nin GYİH değerleri, Çizelge 7 verilmektedir [20]. 
Çizelge 7. GYÏH 2015 değerleri ve oran tablosu.

\begin{tabular}{|l|c|}
\hline \multicolumn{1}{|c|}{ Ülke/Birlik } & US Dolar \\
\hline Avrupa Birliği & 37.148 \\
\hline Amerika & 55.805 \\
\hline Türkiye & 20.438 \\
\hline Türkiye/AB GYïH Oranı (\%) & $\% 55$ \\
\hline Türkiye/ABD GYïH Oranı (\%) & $\% 37$ \\
\hline
\end{tabular}

$\mathrm{Bu}$ durumda 2015 yılı verilerine güncelleme yapıldığında, aşırı rahatsız ve rahatsız kişilerin sayısındaki azalma için 104 Euro/rahatsız kişi/yıl olarak verilen gürültünün ekonomik değeri Türkiye için yaklaşık 57,2 Euro/rahatsız kişi/yıl olarak elde edilmektedir. Bu değer Euro/Dolar parite dönüşümü yapıldığında yaklaşık 63,5 \$/rahatsız kişi/yıl olarak elde edilmektedir.

\subsubsection{Gürültü̈ Bariyeri İnşa Maliyeti}

Bu bölümde kıyaslama açısından yurtiçi ve yurtdışı beton gürültü bariyeri imalatına ait analiz bölümü verilmektedir. Amerikan Federal Karayolu İdaresi (FHWA) tarafindan hazırlanan 2010 yılı verilerine dayalı olarak bariyer yüksekliğine bağlı olarak bariyer tipinin birim fiyatı verilmektedir [21].

Buna göre $7 \mathrm{~m}$ beton bariyer için ortalama birim inşa maliyeti, yıllık enflasyon oranı Amerika için yaklaşık $\% 2$ olarak kabul edilerek, fiyat güncellemesi yapıldığında, 2015 yılı için yaklaşık $380 \$ / \mathrm{m}^{2}$ olmaktadır. Avrupa geneli için, gürültü bariyeri ile ilgili bariyer türüne bağlı olarak verilmiş detaylı bir maliyet çalışması veri tabanı bulunmamaktadır. Avrupa Yol Yöneticileri Birliği (Conference of European Directors of Roa-CEDR) üyesi olan ülkelerin $\% 80$ 'inde gürültü bariyerlerinin bakımı ile ilgili bir prosedür bulunmamaktadır. Maliyetler ülkeden ülkeye değişse de genel olarak inşa maliyeti olarak $400 € / \mathrm{m}^{2}$ ve bakım maliyeti olarak da $77 € / m$ (yükseklikten bağımsız) alınması tavsiye edilmektedir [22]. T.C. Merkez Bankası 2015 yll ortalama Euro/Dolar paritesine göre Avrupa için inşa maliyeti yaklaşık olarak 440 $\$ / \mathrm{m}^{2}$ ve genel bakım maliyeti $84,5 \$ / \mathrm{m}$ hesaplanmaktadır.

Türkiye'de gürülttï bariyerlerinin inşa ve bakım maliyetleri ile ilgili herhangi bir çalışma bulunmamaktadır. Bu konuda Çevre ve Şehircilik Bakanlı̆̆ı'nın her yıl yayımladığı yapı yaklaşık birim maliyet cetveli değerlendirilebilir. 2015 yılında yayımlanan maliyet cetveline göre, 2-A grubu yapılar olan "palplanjlı ve ankrajlı perde ve istinat duvarları" ile gürültü bariyerleri yapısal olarak benzeştirilerek 2-A grubundaki "ve benzeri diğer yapılar" başlı̆̆ altında incelenebileceği düşünülmüştür. Buna göre yapı birim yaklaşık maliyeti istinat duvarları için $270 \mathrm{TL} / \mathrm{m}^{2}$ (yaklaşık $100 \$ / \mathrm{m}^{2}$ ) olarak verilmiştir [23]. Beton gürültü bariyeri inşa maliyeti Amerika için $380 \$ / \mathrm{m}^{2}$ (Transfer Metodu ile Türkiye için $140 \$ / \mathrm{m}^{2}$ ), Avrupa için $440 \$ / \mathrm{m}^{2}$ (Transfer Metodu ile Türkiye için $242 \$ / \mathrm{m}^{2}$ ) ve Türkiye için $100 \$ / \mathrm{m}^{2}$ olarak elde edilmektedir. Hesaplarda gürültü bariyeri inşa maliyeti olarak $100 \$ / \mathrm{m}^{2}$ değeri kullanılacaktır. 


\subsubsection{Perlitli Kaplamanın Inşa Maliyeti}

Perlitli kaplama malzemesine yakın ürünler incelendiğinde, $33 \times 33 \mathrm{~cm}$ granit seramik kaplama malzemesinin (Bakanlık Poz No: 26.007-103C Açıklama: 33x33cm düz yüzeyli, her renk desenli sırlı porselen (granit) karo ile fugalı duvar ve cephe kaplama yapılması) fiyat davranışı ile örtüşen yıllara sari fiyat değişikliği olacağı öngörülmüştür.

Bu malzemenin seçilmesindeki bazı temel hususlar şunlardır:

•Her iki ürünün imalatında doğal kaynakların (kil ve perlit) kullanılması

•Seramik sektörünün hızlı ve seri üretim teknolojisine sahip olması

•Her iki ürünün de imalatında yüksek sıcaklık işleminin yer alması

•Her iki ürün için de öngörülen imalat boyutlarının benzer olması (yaklaşık 30x30 cm)

-Her iki nihai ürününün de kırılgan ve hassas yapıda olması (taşıma ve montaj maliyetleri açısından). Çizelge 8'de granit seramik ürüne ait ürün fiyat değişimi bulunmaktadır.

Çizelge 8. $33 x 33 \mathrm{~cm}$ boyutlu granit seramik birim fiyat değişim tablosu.

\begin{tabular}{|c|c|c|c|c|c|c|c|}
\hline Yil & 2009 & 2010 & 2011 & 2012 & 2013 & $2014 *$ & $2015^{*}$ \\
\hline $\mathrm{TL} / \mathrm{m}^{2}$ & 24,15 & 24,31 & 22,85 & 23,15 & 25,98 & 24,83 & 25,09 \\
\hline
\end{tabular}

Perlitli kaplama malzemesinin seri üretim yapılabilmesi için detaylı bir maliyet analizi ayrı bir çalışma konusu olabilecek niteliktedir. Bu nedenle perlit kaplama malzemesinin birim fiyatının seri üretim halinde granit seramik gibi değişim gösterdiği ve birim fiyatının yaklaşık 25,09 $\mathrm{TL} / \mathrm{m}^{2}$ (yaklaşık 9,2 $\$ / \mathrm{m}^{2}$ ) olduğu kabul edilmiştir. Bu şekilde perlitli inşa malzemesinin imalat maliyeti için belirli bir birim fiyat belirlenmiştir.

\subsubsection{Bariyer Boyama Maliyeti}

Üzerinde perlitli kaplama olmayan yansıtıcı beton gürültü bariyerinin hem genel boyama hem de grafiti gibi estetik bozuklukları gidermek amacı ile uygulanan koruyucu boyama için silikon esaslı dış cephe boyası (Poz No:27.560/7 Açıklama: Silikon esaslı dış cephe boyası (su bazlı) yapılması ) seçilmiştir. Çizelge 9'da silikon esaslı dış cephe boyasının son yıllardaki birim fiyat değişim tablosu bulunmaktadır.

Çizelge 9. Silikon esaslı dış cephe boyası (su bazlı) yapılması işine ait birim fiyatlar.

\begin{tabular}{|c|c|c|c|c|c|c|c|}
\hline Yil & 2009 & 2010 & 2011 & 2012 & 2013 & $2014 *$ & $2015^{*}$ \\
\hline $\mathrm{TL} / \mathrm{m}^{2}$ & 11,44 & 11,59 & 12,36 & 12,83 & 13,36 & 13,84 & 14,35 \\
\hline \\
e Bayındırlık pozu 2014 ve 2015 yılları için bu kod altında yayımlanmadığ için regresyon analizi ile elde \\
edilmiştir.
\end{tabular}


Üzerinde perlitli kaplama bulunmayan beton gürültü bariyerinin boyanması işi birim

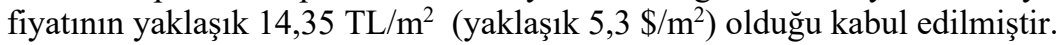

\subsubsection{Perlit Kaplama Plakası Tıkanıklık Temizleme Maliyeti}

Üzerinde perlitli kaplama olan yutucu beton gürültü bariyerinin yutuculuk oranı yıllara göre trafik kaynaklı kirleticilerden dolayı gözeneklerin tıkanması ile düşmektedir. Bu durumda başlangıç yılında elde edilen akustik performans yıllar geçtikçe azalmakta ve bariyerin akustik performansı da giderek bozulmaktadır. Bu durum poroz beton ve poroz asfalt olarak da kullanılan yol yüzey kaplama malzemelerinde de meydana gelmektedir. Yol yüzeyi hem vakumlanıp hem de basınçlı su ile yıkanarak gözenekler ve gözenekler arası kanalların açık kalması sağlanmaya çalışılmaktadır. Dikey konumlanmış gürültü bariyerinin tıkanması, kirleticilerin araç lastikleri ile taşınması daha kolay olduğundan, poroz asfalt veya poroz betona göre daha zordur.

Burada perlitli kaplama malzemesinin tıkanmasına sebep olabilecek belli başlı hususlar şunlar olabilir;

- Taşıt egzoz emisyonlarından kaynaklanan kirletici partiküller

- Araçların çamurlu su sıçratması

- Kar kürüme araçlarının kirli kar yığınlarını yol kenarındaki bariyere doğru kürümesi

- Yük taşıyan araçlardan dökülebilecek kirletici malzemeler

- Kuş, böcek ve bitkiler tarafından taşınan malzemeler ile sarmaşık tipi bitkilerin kaplamayı örtmesi.

Birim maliyet çalışmalarında Karayolları Genel Müdürlüğü’nün yayımladığı birim fiyat cetvelinde yer alan 'benzer işler'den faydalanılmıştır. Yol süpürgesinin yol yüzeyi üzerinde gerçekleştirdiği temizlik işlemi (Poz No: KGM/03.554/1 Açıklama: Süpürge makinasının (vakumlu) 1 saatlik ücreti (yaklaşık $130 \mathrm{HP}+81 \mathrm{HP}$ gücünde) benzer işlem olarak seçilmiştir. Çizelgeden (10) de görüleceği üzere birim fiyat cetveline bu iş kalemi 2012 yılında alınmıştır.

Çizelge 10. Yol süpürme makinası işletme birim fiyat tablosu.

\begin{tabular}{|c|c|c|c|c|c|c|c|}
\hline Y1l & 2009 & 2010 & 2011 & 2012 & 2013 & 2014 & 2015 \\
\hline TL/saat & - & - & - & 139,36 & 149,68 & 168,88 & 161,45 \\
\hline
\end{tabular}

Verilen birim fiyat ücreti TL/saat bazında verilmiş olduğundan bunun bariyer üzerindeki işlemlere uygulanabilmesi için $\mathrm{TL} / \mathrm{m}^{2}$ cinsine çevrilmesi gerekmektedir. Bu noktada seçilen aracın dikey konumlanmış bariyeri temizleyebilmesi için aşağıdaki kabuller yapılmıştır.

- Seçilen araç ile 1 saatte $400 \mathrm{~m}^{2}$ bariyer alanı temizlenebilmektedir.

- Araç yol-bariyer mesafesi olan $4 \mathrm{~m}$ mesafede rahatlıkla engelsiz bir şekilde çalışabilmektedir. 
- Aracın bariyer yüksekliği olan 7 m'ye ulaşabilecek uygun donanımı mevcuttur.

- Araç 1 seferde yaklaşı1k $400 \mathrm{~m}^{2}$ bariyer alanını süpürüp yıkamaya yetecek kadar atık haznesi ve su deposuna sahiptir.

Perlitli kaplama malzemesinin 1 saatte gerçekleştirebileceği temizlenme alan miktarı değiştikçe maliyet de değişecektir. Temizlenme alanı ise temizleme süresini belirleyen araç temizleme kapasitesi ile operatöre bağlıdır. Bu iş kalemi içinde aracın çalışması için gerekli olan yakıt, aracın kendi amortisman değeri ve bir adet operatör makinist ve bir adet operatör yardımcının maliyetleri yer almaktadır. Bu şekilde perlitli inşa malzemesinin vakumlu makine ile temizlenmesi maliyeti için belirli bir birim fiyat belirlenmiştir.

Yurtdışında özellikle araç park sahalarında kullanılan poroz asfalt ve poroz beton asfalt kaplamaların vakum makinesi ile yılda 3-4 kez temizlenme sıklığı ile temizleme maliyeti $2000 \mathrm{~m}^{2}$ lik bir park alanı için 400\$-500\$ olarak verilmektedir [24] Bu durumda Türkiye'deki temizleme işleminin de yapılan kabuller çerçevesinde birim fiyatı yaklaşık (tek seferde yapılacak bir işlem için) $0,15 \$ / \mathrm{m}^{2}$ (yaklaşık $0,4 \mathrm{TL} / \mathrm{m}^{2}$ ) olarak hesaplanmaktadır.

\subsubsection{Yıllık Enflasyon Oranının Belirlenmesi}

Uzun süreli tahmin modellerinde kullanmak üzere projelerde alınması öngörülen 2015, 2020 ve 2050 yılları için enflasyon oranlarının farklı kaynaklarda farklı değerlerine rastlamak mümkündür. Enflasyon 2015 yılı için \%8,8 olarak gerçekleşmiştir. Trading Economics Firmasının enflasyon tahminlerine göre 2020 yılı için \% 6,1 ve 2030 yılı için \%4,08 değerleri öngörülmektedir [25] İngiliz Pwc Firması ise enflasyon tahminini 2017 yılı için \% 7,5 ve 2022'ye kadar da \%7,0 olarak vermektedir [26]. Türkiye'deki Ulaşım Altyapısının Değerlendirilmesi için Teknik Destek başlığı ile hazırlanan Avrupa Birliği projesinde ise bu değerler 2023 yılı için \%4 ve 2050 yılı için de \%3 olarak verilmektedir [27]. Bu verilerden yola çıkarak bu çalışmadaki fiyat güncellemeleri aşağıdaki Tabloda (11) yer alan tarihlere karşılık gelen ve güvenli tarafta kalınarak alınan yaklaşık değerler ile yapılacaktır:

Çizelge 11. Türkiye için tahmini uzun dönem enflasyon değerleri.

\begin{tabular}{|c|c|c|c|c|}
\hline Yıllar & $\mathbf{2 0 1 5 - 2 0 2 0}$ & $\mathbf{2 0 2 0 - 2 0 3 0}$ & $\mathbf{2 0 5 0}$ 'ye kadar & 2050 sonrası \\
\hline Enflasyon Oranı & $\% 7,0$ & $\% 5,0$ & $\% 5,0$ & $\% 4,0$ \\
\hline
\end{tabular}

\subsubsection{Faydanın Net Bugünkü Değere Çevrilmesi}

Verilen bu değerlere göre Fayda Transfer Metodu (Basit Birim Transferi Metodu) uygulandığında elde edilen gürültünün ekonomik fayda değeri belirlenerek, fayda değeri özet Tablosu (12) verilmektedir [26, 27, 28]. 
Çizelge 12. Perlitli kaplama ile elde edilen gürültü azaltımının indirgenmis fayda değeri.

\begin{tabular}{|c|c|c|c|c|}
\hline Durum & $\begin{array}{r}\text { Kişi sayısı } \\
\% \mathrm{HA}+\% \mathrm{~A}\end{array}$ & $\begin{array}{c}\Delta \text { Fark } \\
(\% \mathrm{HA}+\% \mathrm{~A} \\
\text { kişi sayısı) }\end{array}$ & $\begin{array}{l}50 \text { yıl için } \\
\text { indirgenmiş } \\
\text { fayda değeri } \\
(\text { US \$ })^{1}\end{array}$ & $\begin{array}{c}50 \text { yıl için } \\
\text { kaplamanın } \\
\text { fark fayda } \\
\text { değeri (US \$) }\end{array}$ \\
\hline Bariyersiz & 109 & - & - & - \\
\hline $\begin{array}{l}\text { Yansitıci } 7 \mathrm{~m} \\
\text { bariyer }\end{array}$ & 77 & 32 & $224.941 \$$ & - \\
\hline Yutucu $7 \mathrm{~m}$ bariyer & 66 & 43 & $302.264 \$$ & $77.323 \$$ \\
\hline
\end{tabular}

\subsubsection{Maliyetlerin Net Bugünkü Değere Çevrilmesi}

Maliyet hesabında Türkiye'deki yapım işlerine ait malzemelerdeki fiyatlar referans olarak alınmış ve daha önce verilen 50 yıllık enflasyon oranları üzerinden hesaplamalar gerçekleştirilmiştir. Yapılan maliyete ait kabuller ve değerler (2015 yılı) özet olarak aşağıda siralanmaktadır:

Bariyer inşa maliyeti $100 \$ / \mathrm{m}^{2}$

Perlit kaplama maliyeti $9,2 \$ / \mathrm{m}^{2}$

Perlitli kaplama tıkanıklık temizleme

$0,15 \$ / \mathrm{m}^{2}$

Bariyer genel ve koruyucu boyama

$5,3 \$ / \mathrm{m}^{2}$

Diğer genel kabullerin özeti aşağıda sıralanmaktadır:

Bariyer ömrü $\quad 50$ yil

Bariyer uzunluğu

$80 \mathrm{~m}$

Bariyer yüksekliği

$7,0 \mathrm{~m}$

Perlit kaplama yenileme sıklığ 1

Y1lda 1 kez toplam alanın $\% 5$ 'i

Tıkanıklık temizlik sıklığı

Yilda $2 \mathrm{kez}$

Bariyer genel boyama sıklığı

20 yilda $1 \mathrm{kez}$

Bariyer koruyucu boyama sıklığg

5 yılda $1 \mathrm{kez}$ toplam alanın $\% 1$ 'i

Bariyer kısmi değişimi

10 yılda $1 \mathrm{kez}$ toplam alanın \%1'i

Bariyer çevresel temizliği ve genel bakım

Yilda $1 \mathrm{kez}$ (maliyet: $51,1 \$ / \mathrm{m})$

Yapılan maliyet hesapları aşağıdaki 3 durum için gerçekleştirilmiştir (Bağıntı 6);

Durum 1: Bariyersiz duruma göre yansıtıcı BA bariyer inşası durumu

Durum 2: Bariyersiz duruma göre perlit kaplamalı BA bariyer inşası durumu

Durum 3: Yansıtıcı bariyerli duruma göre perlit kaplama inşası durumu. 
$\Delta \sum_{t=0}^{50} M_{t}=\sum_{t=0}^{50} M_{p k}-\sum_{t=0}^{50} M_{y b}$

$\mathrm{M}_{\mathrm{t}}$ : Toplam net maliyet (durum 3)

$\mathrm{M}_{\mathrm{pk}}$ : Perlit kaplamalı gürültü bariyeri maliyeti

$\mathrm{M}_{\mathrm{yb}}$ : Yansıtıcı bariyer maliyetidir. İndirgenmiş maliyet değerleri Tablosu 13'deki gibidir [29, 30].

Çizelge 13. İndirgenmiş maliyet değerleri tablosu.

\begin{tabular}{|c|c|c|}
\hline Durum & $\begin{array}{c}\text { İndirgenmiş maliyet değeri } \\
\text { (US \$) }\end{array}$ & $\begin{array}{c}\text { Perlit esaslı kaplamanın fark } \\
\text { maliyet değeri (US \$) }\end{array}$ \\
\hline Bariyersiz & - & - \\
\hline Yansitıcı 7m bariyer & $167.389 \$$ & - \\
\hline Yutucu 7m bariyer & $204.466 \$$ & 37.077 \$ \\
\hline $\begin{array}{l}\text { 1 } 50 \text { y1l için her bir durumun bariyersiz duruma göre toplam maliyet fark değeri } \\
\text { 2 } 50 \text { y1l için perlit kaplamalı durumun yansıtıcı bariyer durumuna göre ek maliyet fark değeri }\end{array}$ \\
\hline
\end{tabular}

\subsection{Fayda Maliyet Analizi}

Beton gürültü bariyerinin inşası ile beton gürültü bariyerinin perlitli kaplama olarak inşasının fayda maliyet analizi bu bölümde gerçekleştirilmiş olup, ayrıca her iki durumun birbiri ile kıyaslaması da gerçekleştirilmiştir. Perlitli kaplama malzemesi için elde edilen F/M ve İKO oranı Çizelge 14'de verilmektedir.

Çizelge 14. Perlitli kaplama malzemesi için elde edilen F/M ve IKO oranı tablosu.

\begin{tabular}{|c|c|c|c|c|}
\hline Durum & $\begin{array}{c}50 \text { yıl için fayda } \\
\text { değeri }[\$]^{*}\end{array}$ & $\begin{array}{c}50 \text { yıl için maliyet } \\
\text { değeri }[\$]^{*}\end{array}$ & $\begin{array}{c}\text { F/M } \\
\text { değeri** }\end{array}$ & İKO*** \\
\hline $\begin{array}{l}7 \mathrm{~m} \text { yutucu bariyer inşas } 1 \\
\text { durumu }\end{array}$ & 302.264 & 204.466 & 1,48 & $\% 5,5$ \\
\hline $\begin{array}{l}7 \mathrm{~m} \text { yansitıcı bariyer } \\
\text { inşası durumu }\end{array}$ & 224.941 & 167.389 & 1,34 & $\% 6,4$ \\
\hline $\begin{array}{l}\text { Yansitıcı Bariyerin } \\
\text { Yutucuya çevrilmesi } \\
\text { durumu }\end{array}$ & 77.323 & 37.077 & 2,09 & $\% 12,4$ \\
\hline \multicolumn{5}{|c|}{$\begin{array}{l}\text { * İndirgenmiş fayda ve maliyet değerleri } \\
\text { ** F/M analiz değerinin } \geq 1,0 \text { olması projenin uygulanabilir olduğunu göstermektedir. } \\
\text { *** İndirgenmemiş fayda maliyet nakit akış değerlerinden elde edilmiştir. İKO değerinin indirgeme oranı olara } \\
\text { seçilen } \% 2,5 \text { dan fazla olması, projenin uygulanabilir olduğunu göstermektedir. }\end{array}$} \\
\hline
\end{tabular}

Perlitli kaplama malzemesi için elde edilen NBD ise Çizelge 15 'de verilmektedir. 
Çizelge 15. Perlitli kaplama malzemesi için elde edilen NBD tablosu.

\begin{tabular}{|l|c|c|c|}
\hline \multicolumn{1}{|c|}{ Durum } & $\begin{array}{c}\mathbf{5 0} \text { yıl için fayda değeri } \\
{[\mathbf{\$}]^{*}}\end{array}$ & $\begin{array}{c}\mathbf{5 0} \text { yıl için maliyet değeri } \\
{[\mathbf{\$}]^{*}}\end{array}$ & NBD [\$\$ $]^{* *}$ \\
\hline $\begin{array}{l}7 \mathrm{~m} \text { yutucu bariyer inşası } \\
\text { durumu }\end{array}$ & 302.264 & 204.466 & $\mathbf{9 7 . 7 9 8}$ \\
\hline $\begin{array}{l}7 \mathrm{~m} \text { yansitıcı bariyer inşası } \\
\text { durumu }\end{array}$ & 224.941 & 167.389 & $\mathbf{5 7 . 5 5 2}$ \\
\hline $\begin{array}{l}\text { Yansitıcı Bariyerin } \\
\text { Yutucuya çevrilmesi } \\
\text { durumu }\end{array}$ & 77.323 & 37.077 & $\mathbf{4 0 . 2 4 6}$ \\
\hline $\begin{array}{l}\text { * İndirgenmiş fayda ve maliyet değerleri } \\
* * \text { NBD'in }>0 \text { olmasi projenin uygulanabilir olduğunu göstermektedir. }\end{array}$ \\
\hline
\end{tabular}

Çizelgedeki sonuçlar perlit kaplamanın maliyet analizi sonucunda uygulanabilir olduğunu göstermektedir.

\section{SONUÇLAR}

Türkiye'de oldukça zengin şekilde bulunan perlitin bir kaplama malzemesi olarak gürültü bariyerlerinde kullanımının uygun olup olmadığının irdelendiği bu çalışmada, patlatılmış perlitin yüksek sıcaklık altında camsılaştırma ve ardından soğutma işlemlerinden sonra kazandığı gözenekli yapı ile iyi bir ses yutucu yapıya kavuştuğu görülmüştür. Perlit esaslı kaplama ile kaplanan bir bariyer, gerçekleştirilen akustik testler sonucunda belirlendiği üzere TSEN 1793-1 Standardına göre A2 sınıfı ses yutuculuğa sahip gürültü bariyeri olarak sınıflandırılmaktadır. Piyasada yer alan birçok gürültü bariyerinin ses yutum performansı A2 sınıfında yer aldığından bu özelliği ile perlitli kaplamanın trafik gürültüsü ile mücadelede kullanılabilecek nitelikte olduğu görülmektedir.

Gürültü haritalama sonuçlarının, etkilenen kişi sayılarındaki yüzdesel değişiklik cinsinden verilmesi sonuçların nüfusa bağlı olmadan, istenilen parametreler için değişiminin izlenmesine olanak vermektedir. Bu durum sonuçların esnek bir şekilde yorumlanmasını da olanaklı kılmaktadır. Böylelikle seçilen alandaki nüfus yoğunluğu arttığında, etkilenen (rahatsız ve aşırı rahatsız) kişi sayısındaki değişim yüzdesel olarak nüfusa yansıtılarak yeni kişi sayıları üzerinden yeni bir fayda hesabı gerçekleştirilmesine, böylelikle ekonomik analizlerin kolaylıkla yeniden yapılabilmesine imkan sağlamaktadır. Hatta gürültü ölçüm zaman dilimleri için gün içi nüfus (gündüz ve gece farklı nüfus sayıları) değişikliklerinin olması durumunda fayda değerleri yeniden hesaplanabilecektir. (F/M oranı, İKO ve NBD) değerlendirmesinde perlit esaslı kaplamalı gürültü bariyer inşasının belirlenen alan ve koşullar için ekonomik olarak faydalı olacağı saptanmıştır. Ülkemizdeki rezervi oldukça fazla olan perlitin değerlendirilme yollarından biri olarak perlitli bariyer kaplamasının gürültü azaltma açısından etkin ve ekonomik olduğu bu makalede detaylı olarak ortaya konmaktadır. Kaynaklarımızın etkin kullanımı ülkemizin kalkınması için üzerinde önemle 
durulması gereken konulardan biridir. Bu nedenle tarafımızca çalışmanın ve sonucunun önemli olduğu düşünülmektedir.

\section{Kaynaklar}

[1] Çevresel Gürültünün Değerlendirilmesi Ve Yönetimi Yönetmeliği (2015). T. C. Resmi Gazete, 29536, 18 Kasim 2015.

[2] Houssa, C. E. (1999). Talking Turkey, An Update on the Turkish Minerals Industry. Industrial Minerals, 379, 21-47.

[3] Uyanık, T. (2010). Sektörel Rapor: Madencilik (HS: 25,26,27,6802). Ankara: Ekonomi Bakanlığı İhracatı Geliştirme Etüd Merkezi (İGEME) Raporu.

[4] Bolen, W. P. (2011). USGS Mineral Commodity Summaries 2011. U.S. Geological Survey.

[5] ASTM. (2002). Standard Test Method for Sound Absorption and Sound Absorption Coefficients by the Reverberation Room Method. (ASTM C423-02).

[6] TSE. (2002). Yol Trafik Gürültüsünü Azaltan Sistemler Akustik Performansın Tayini İçin Deney Metodu Bölüm 1: Ses Absorpsiyonunun Temel Özellikleri (TS EN 17931). Erişim: http://www.tse.org.tr.

[7] Morgan, S. M., Kay, D. H., \& Bodapati, S. N. (2001). Study of Noise Barrier LifeCycle Costing, Journal of Transportation Engineering, 127(3), 230-236.

[8] Navrud, S. (2011). State-of-the-art in Valuation of Transportation Noise [Power Point Sunumu]. Erişim Tarihi: 7 Haziran 2016 Adres: http://www.czp.cuni.cz/tranext/files/6-Navrud-State-of-the-art_in_valuation_of_transportation_noise.pdf

[9] ISO. (2003). Acoustics - Assessment of noise annoyance by means of social and socio-acoustic surveys. (ISO/TS 15666). Erişim: http://www.tse.org.tr.

[10] Nijland, H., \& Wee, B. (2008). Noise valuation in ex-ante evaluations of major road and railroad projects. EJTIR, 3(8), 216-226.

[11] Kroes E. P., Sheldon R. J. (1988). Stated Preferences Methods, Journal of Transport Economics and Policy, Vol XXII, No:1, p 11-25.

[12] Salverda, M., \& Hawkins, R. (2003). ICRA Learning Resources: Cost Benefit Analysis

[13] European Commission Working Group On Health And Socio-Economic Aspects. (2003). Valuation of Noise Position Paper. Erişim tarihi: 1 Ocak 2016, Adres:http://ec.europa.eu/environment/noise/pdf/valuatio_final_12_2003.pdf.

[14] Morgan, S. M., Kay, D. H., \& Bodapati, S. N. (2001). Study of Noise Barrier LifeCycle Costing, Journal of Transportation Engineering, 127(3), 230-236.

[15] WHO. (1980). WHO Environmental Health Criteria 12-Noise. Geneva: World Health Organisation. 
[16] Miedema, M. E., \& Oudshoom, G. M. (2001). Annoyance from transportation noise: relationships with exposure metrics DNL and DENL and their confidence intervals, Environmental Health Perspectives, 109(4), 409-416.

[17] Url-1. < http://www.tcmb.gov.tr/kurlar/kur2015_tr.html>, Erişim tarihi: 01.03.2016

[18] HEATCO. (2006). Developing Harmonised European Approaches for Transport Costing and Project Assessment. Sixth Framework Programme, (Contract No: 2002SSP-1/502481), Stuttgart: European Commission EC-DG TREN. Erişim tarihi: 21 Ocak 2013 Adres: http://www.heatco.ier.uni-stuttgart.de.

[19] Url-2. < https:/www.ecb.europa.eu/stats/prices/hicp/html/inflation.en.html>, Erişim tarihi: 09.05.2016.

[20] Url-3. <http://www.tuik.gov.tr/PreHaberBultenleri.do?id=21510>, Erişim tarihi: 09.05.2016.

[21] FHWA. (2010). Noise Barrier design handbook. Erişim tarihi: 14 Mayıs 2011, Adres:http://www.fhwa.dot.gov/environment/noise/noise_barriers/design_constructio $\mathrm{n} /$ design/index.cfm

[22] Value for Money in Road Traffic Noise Abatement (Report: CEDR Road Noise 20092013). Paris: Conference of European Directors of Roads (CEDR).

[23] Mimarlık Ve Mühendislik Hizmet Bedellerinin Hesabında Kullanılacak 2015 Y1lı Yap1 Yaklaşık Birim Maliyetleri Hakkında Tebliğ (2013). T. C. Resmi Gazete, 29300, 19 Mart 2015.

[24] WisDOT Research \& Library Unit. (2012). Transportation Synthesis Report: Comparison of Permeable Pavement Types. (Rapor No: TSR-2011). Wisconsin: WisDOT Research \& Library Unit Report.

[25] Url-4. <http://tr.tradingeconomics.com/turkey/forecast>, Erişim tarihi: 05.06.2016.

[26] Url-5<http://www.pwc.co.uk/economic-services/global-economy-watch/gewprojections.jhtml>, Erişim tarihi: 06.06.2016.

[27] Mueller, R. (2007). Technical Assistance to Transportation Infrastructure Needs Assessment for Turkey. Final Report (TINA Turkey) Joint Venture.

[28] DataKustik CadnaA Noise Prediction Software (Versiyon 4.1) [Computer Software]. Greifenberg, Germany: DataKustik GmbH. 
